Breilid, N. \& Dyrnes, E. M. (2017). Bestyrkende faktorer som fremmer en positiv overgang fra skole til varig arbeidslivstilknytning for elever i lærekandidatordningen i Scandinavian Journal of Vocations in Development.

http://dx.doi.org/10.7577/sjvd.2179

Peer reviewed article

(fagfellevurdert artikkel)

\title{
Bestyrkende faktorer som fremmer en positiv overgang fra skole til varig arbeidslivstilknytning for elever $i$ lærekandidat-ordningen.
}

Forfattere

Nils Breilid

Høgskolen i Oslo og Akershus, Fakultet for lærerutdanning og internasjonale studier, Institutt for Yrkesfaglærerutdanning

Eva Martinsen Dyrnes

Høgskolen i Østfold, Avdeling for lærerutdanning

\section{Nøkkelord:}

Spesialundervisning, Lærekandidatordningen, Overgang skole - yrkesliv, Empowerment 


\begin{abstract}
Introduction: This study deals with young people receiving special needs education in schools and their transition to lasting employment in private or public sector. Through a qualitative approach, the article aims at "identifying significant factors which can, contribute to successful transitions from school to lasting employment affiliation for pupils in vocational training programs"
\end{abstract}

Theoretical approach: The theoretical approach of this article is descriptions and interpretation of the Norwegian educational legislation and the theory of «empowerment». These theoretical perspectives will be included in the empirical discussion.

Method: The methodological approach is qualitative. Through four semi-structured interviews of young informants who have completed upper secondary school in a vocational education program, and have had a minimum of one-year training in an enterprise. Thematic analysis of the data is conducted with the application of NVivo 11, a computer program that is suitable for qualitative data-analysis and mixed research methods.

Results and discussion: Through thematic analysis of the data, we found three significant factors contributing to successful transitions from school to lasting employment:

a) Application and development of the pupil's competence - mastery and meaning

b) The significance of relations, communication and well-functioning socio-ecological networks

c) The importance of pupil participation and involvement in decision making 


\section{Innledning}

Mye tyder på at overgangen fra videregående opplæring til yrkeslivet er kritisk både med tanke på samfunnsøkonomi, folkehelse og enkeltindividers muligheter til aktiv og meningsfull samfunns- og yrkesdeltakelse (Meld. St. nr. 20 (2012-2013), 2013, s. 42). Overgangen mellom skole og arbeidsliv kan innebære store utfordringer for alle elever i en tid der arbeidsmarkedet rommer færre og kravene til kompetanse både blir større og er i stadig endring (Utdanningsdepartementet, 2006) I Opplæringslovens formålsparagraf § 1-1, sies det i første ledd at «opplaringa skal, $i$ samarbeid og forståing med heimen, opne dører mot verda og framtida....». Opplæringsloven påpeker her betydningen av elevens sosio-økologiske nettverk med tanke på innholdet i opplæringen og overgangen mellom skole og varig arbeidslivstilknytning. I formålsparagrafens 5. ledd presiseres det at skolens ansvar er å bidra til at «Elevane og larlingane skal utvikle kunnskap, dugleik og holdningar for å kunne meistre liva sine og for å kunne delta $i$ arbeid og fellesskap $i$ samfunnet». Elevene skal derfor, gjennom gode tilretteleggingstiltak i skolen og samarbeid med hjemmet, «opne dører mot verda og framtida» med tanke på danning av «det integrerte mennesket»(Opplæringslova, 2007). Dette innebærer bl.a. å legge til rette for utviklingen av selvstendige og uavhengige personligheter - og evne til å virke og arbeide i lag. Formålsparagrafens sjette ledd betoner at elevene «skal ha medansvar og rett til medverknad» i eget lærings- og arbeidsliv. Å bestyrke kunnskapsmessig, sosial og holdningsmessig kompetanse med tanke på aktiv samfunnsdeltakelse i et samarbeid mellom elev, hjem og skole blir dermed en kjerneaktivitet i dagens videregående skole. Disse føringene gjelder alle elever, både elever i ordinær opplæring og elever i spesialpedagogiske tilbud. I Opplæringslovens kapittel 5 slås det fast at elever som ikke har tilfredsstillende utbytte av ordinær, tilpasset opplæring, har rett til spesialundervisning (Opplæringslova, 2007). I vurderingen av hvilket opplæringstilbud som eleven skal ha, skal elevens utvikling og framtidsutsikter vektlegges. Opplæringstilbudet for elever med spesialundervisning skal vektlegge realistiske opplæringsmål for eleven. I den forstand vil det være viktig at opplæringstilbudet i skolen har et tydelig framtidsfokus som også kan innebære varig arbeidslivstilknytning.

I den norske skolen råder ulike syn og perspektiver på spesialpedagogikk og spesialundervisning (Befring \& Tangen, 2012; Tangen, 2014a). Det refereres gjerne til tre ulike perspektiv: det individuelle, hvor utfordringene defineres i eleven; det sosiale, hvor utfordringene defineres i konteksten, og det relasjonelle, hvor utfordringene defineres i 
samspillet mellom elevens forutsetninger og kontekstuelle betingelser (Tangen, 2014a). Skolen preges i ulik grad av slike perspektiv - og perspektivene vil trolig også påvirke elevens lærings- og utviklingsmuligheter.

Det finnes forholdsvis lite forskning som omhandler elever med spesialundervisning på yrkesfaglige utdanningsprogram og deres vei til yrkesdeltakelse hvor elevene selv bringer fram sine opplevelser og erfaringer om hva som kan bidra positivt for overgangen mellom skole og arbeidsliv (Buli-Holmberg, 2015). Dette ble vårt utgangspunkt for å intervjue ungdom i lærekandidatordningen, et tilbud i videregående opplæring til elever som går mot grunnkompetanse, om deres vei fra skole til arbeidsliv.

All ungdom som fullfører grunnskole eller tilsvarende har rett til tre års videregående opplæring som kan gjennomføres over en periode på fem år. I opplæringslovens kapittel $3, \S$ 3-3 slås det fast at videregående opplæring skal føre fram til studiekompetanse, yrkeskompetanse eller grunnkompetanse, som er tre likeverdige kompetanser (Opplæringslova, 2007). Elever som gjennomfører og består yrkesfaglige utdanningsprogram på videregående skole med to års opplæring i skole og to års opplæring i bedrift, avslutter opplæringen med yrkeskompetanse/fag eller svennebrev i faget. Lærekandidatordningen har som siktemål at eleven skal gjennomføre opplæringen for å oppnå kompetansebevis som er en dokumentasjon på en mindre omfattende kompetanse enn et fag-/svennebrev.

Lærekandidatordningen kan derfor være et godt alternativ for elever som ikke har de nødvendige forutsetningene for å gå opp til fag/svenneprøve. Ordningen innebærer at kandidaten oppnår grunnkompetanse, som i etterkant, og etter gitte regler, kan utvides til full yrkeskompetanse. Dette er en ordning som er aktuell for elever som stryker i fag, velger bort fag, slutter i løpet av utdanningen eller av andre årsaker, f.eks. manglende faglige eller sosiale forutsetninger, har vansker med å gjennomføre et ordinært yrkesfaglig utdanningsforløp. Den siste gruppen er gjerne elever som mottar spesialundervisning for å sikre en likeverdig opplæring i videregående skole. Skolen har et klart ansvar når det gjelder å tilrettelegge opplæringen med lærekandidatordningen som mål (Opplæringslova, 1998).

For elever med grunnkompetanse som mål, kan muligheter for en varig tilknytning til arbeidslivet være utfordrende (Buli-Holmberg, 2015). Disse elevene vil trolig ha behov for individuell bistand fra skole, bedrift og andre eksterne aktører for å sikre en god overgang og en varig tilknytning til yrkeslivet. Forfatterne av denne artikkelen har vært tilknyttet en 
forskergruppe med fokus på lærekandidaters overgang til en varig arbeidslivstilknytning. Forprosjektet som danner datagrunnlag for denne artikkelen er finansiert av Oslofjordfondet.

I denne artikkelen ønsker vi å identifisere faktorer som kan bidra til å styrke elevens mestring av overgangen fra skole til varig arbeidslivstilknytning. Statistikk viser at elever på yrkesfaglige program får spesialundervisning i betydelig større grad enn elever på studiespesialiserende program (Markussen, 2009; Markussen, Frøseth \& Grøgaard, 2009). Forskning indikerer også at spesialundervisning ofte er knyttet til tradisjonell opplæring som i liten grad har maktet å kvalifisere elever for yrkeslivet (Berzin \& Kelly, 2009; Guy, Sitlington, Larsen \& Frank, 2009). I denne artikkelen har vi til hensikt å identifisere ulike faktorer som kan bidra til å sikre gode overganger mellom videregående skole og bedrift, og som samtidig kan $\varnothing$ ke sannsynligheten for varig tilknytning til arbeidslivet. Hva lærekandidater med spesialpedagogiske tilbud opplever som viktig med tanke på myndiggjøring og tilrettelegging for overgang til yrkesdeltakelse blir dermed problemstillingen for denne artikkelen; Hvilke bestyrkende faktorer kan fremme positive overganger fra skole til varig arbeidslivstilknytning for elever i larekandidatordningen?

\section{Sentrale faktorer med betydning for overgangen til et varig yrkesliv}

Skolen er den viktigste livsarenaen for barn og unge utenfor familien (Breilid, 2007). Den kvaliteten elevene opplever i skolen, på vei mot en varig arbeidslivstilknytning, kan betegnes som skolelivskvalitet. En forutsetning for å etablere innsikt i erfaringer med skole og overgang til en varig arbeidslivstilknytning må være å lytte til elevenes stemmer (Lassen \& Breilid, 2012; Tangen, 2014a). God skolelivskvalitet vil i vår sammenheng også ha de kvalitetene som elevene opplevde at skolen la opp til i arbeidet med overgang til varig arbeidslivstilknytning. Hvordan de ulike spesialpedagogiske perspektivene har preget skoleog arbeidslivskontekster har derfor vært tydelig i vår studie.

Det spesialpedagogiske forskningsfeltet er relativt stort med tanke på tradisjonelle temaer som lese og skriveproblematikk, atferdsproblematikk, generelle lærevansker osv., mens spesialundervisning i videregående opplæring som nevnt er viet relativt lite oppmerksomhet (Buli-Holmberg, 2012; Tangen, 2014b). European Agency for Development in Special Needs Education (European Agency for Special Needs and Inclusive Education, u.å.) har imidlertid gjennomført et større prosjekt. Gjennom prosjektet ble ulike aspekter av utdanning og praksis for elever med behov for særskilt hjelp og støtte i alderen 14 til 25 år, identifisert og 
undersøkt. En viktig målsetting i prosjektet var å utvikle kunnskap om koblingene mellom elevenes utdanningsvalg og deres muligheter for varig arbeidslivstilknytning. Prosjektet bygger på data fra litteraturstudier, samt at 50 sakkyndige bes $\varnothing$ kte 28 land i Europa og studerte og analyserte «hva som fungerer», «hvorfor det fungerer» og «hvordan det fungerer» i de ulike prosjektlandene (European Agency for Special Needs and Inclusive Education, u.å.). Prosjektet identifiserte 20 nøkkelfaktorer som beskrives som nødvendige for å sikre gode overganger mellom skole og arbeidsliv for elever med spesielle behov. Eksempler på betydningsfulle faktorer er f.eks. at lovgrunnlaget for virksomheten er av inkluderende natur. Det må videre legges til rette for tilpassing av opplæringen med utgangspunkt i elevens evner og forutsetning i samarbeid med elev, foresatte, skole og støtteapparatet rundt eleven. Dette forutsetter høy real og formalkompetanse hos det pedagogiske personalet som både sikrer målrettet kvalitet i opplæringen, samt et godt nettverk ut i aktuelle bedrifter. Videre krever dette også et godt utviklet partnerskap mellom skole og bedrifter; elev-orientert tilnærming som sikrer eleven muligheter for medvirkning og medbestemmelse; matching av elevens kompetanse med bedriftens behov. Vi kan lese ut av dette at faktorer som elevenes forutsetninger og motivasjon, samt at elevene har kompetente sosio- $\varnothing$ kologiske nettverk er av stor betydning for at overgang fra skole til en varig arbeidslivstilknytning skal bli vellykket. Ulike faktorer som bidrar til bestyrking av elevene og elevenes nettverk vil derfor bli unders $\varnothing \mathrm{kt}$ og belyst videre i artikkelen.

\section{Et bestyrkende perspektiv}

Konklusjoner fra tidligere forskning og anbefalinger er at samarbeid mellom og myndiggjøring av elev, foresatte og pedagogisk personale, i overgangen mellom skole og arbeidsliv er vesentlig (European Agency for Special Needs and Inclusive Education, u.å.; Lassen \& Breilid, 2012). Myndiggjørings- eller bestyrkingsperspektivet er utledet av den engelspråklige termen "empowerment" (Lassen \& Breilid, 2012). Bestyrking innebærer at oppmerksomhet dreies fra å være ensidig fokusert på individenes manglende forutsetninger, til å fokusere på individenes muligheter for funksjon og positive bidrag i samfunnet. Et hovedmål for pedagogisk arbeid vil derfor være å styrke elever med behov for støtte gjennom aktivt og målrettet samspill mellom relevante samarbeidspartnere. Empowerment-perspektivet og myndiggjøring innebærer at egenskaper i elev og miljø som fremmer muligheter for frigjøring og kontroll blir bestyrket (Askheim, 2003; Lassen, 2014; Menon, 2001). Et slikt spesialpedagogisk fokus vil stille store krav til profesjonelle aktører, spesielt til lærere og ansatte i støttesystemene som er rundt eleven, både med tanke på innholdet i opplæringen, 
men også med tanke på utfordrende overganger i en opplærings- og arbeidskontekst (Befring, 2008, s. 29).

I utgangspunktet innebærer empowerment-prinsippet «overføring av makt», og kan relateres til ulike populasjoner som befinner seg $\mathrm{i}$ «avmektige posisjoner» (barn, ungdom, funksjonshemmede, innvandrere etc.). Empowerment-tradisjonen tar sitt utgangspunkt i $\emptyset$ kologisk systemteori, og vektlegger muligheter innenfor ulike $\emptyset$ kologiske nivåer, og hvordan handlinger på disse ulike nivåene kan påvirker aktørene (Bronfenbrenner, 1979). Dette utgjør et viktig grunnlag for bestyrkningstilnærmingen (Askheim, 2003; Dunst, Trivette \& Deal, 1994). Relasjoner og kommunikasjon har derfor en vesentlig funksjon for å fremme utvikling og vekst (Dyrnes, 2013; Lassen \& Breilid, 2010; Menon, 2001; Olaisen, 2007).

Lassen (2008) identifiserer ulike temaer i empowerment-tradisjonen. Et vesentlig perspektiv omhandler kartlegging av utfordringer og styrker i eleven og i systemene rundt elevene med tanke på myndiggjøring av eleven (Egan, 2002; Lazarus \& Folkman, 1991). Et annet sentralt tema er hvordan mennesker og systemer innehar forutsetninger for, med utgangspunkt $\mathrm{i}$ eksisterende ressurser, å styrke egen kompetanse. Dette innebærer en vektlegging av den enkeltes styrker framfor den enkeltes utfordringer. Denne orienteringen kan virke st $\varnothing$ ttende når det gjelder å initiere og utvikle gode relasjoner og god kommunikasjon mellom elev/foreldre og profesjonsutøverne (Lassen \& Breilid, 2010). På denne måten kan elevens muligheter for medbestemmelse og ansvar for egen utvikling fremmes. Uformell og formell mobilisering av støtte fra systemene rundt eleven (Lassen, 2008) vil også øke sannsynligheten for at eleven ivaretas og bestyrkes med tanke på overgang fra skole til varig arbeidslivstilknytning. Med tanke på våre informanter, omhandler dette hvordan de ulike systemene - på ulike nivå samhandler til elevens beste (Befring, 2008). Samarbeid og partnerskap krever gjensidig utvikling av anerkjennende kommunikasjon i det asymmetriske forholdet som alltid vil prege lærer/elev-relasjoner (Lassen \& Breilid, 2010). I tillegg til gode relasjoner og god kommunikasjon vil det være sentralt i en empowerment-tradisjon at eleven opplever mestring. Her må elevenes og systemenes eksisterende kompetanse være grunnlag for å videreutvikle kompetanse (Lassen, 2008; Seligman, 2012). Lassens ulike empowermenttemaer vil inspirere de empiriske analysene i denne artikkelen. 
Empowerment-perspektivet fokuserer på et system- økologisk perspektiv, noe som innebærer å inkludere individets totale livskontekst i bestyrkingsprosessene. Et system- $\varnothing$ kologisk perspektiv vil innebære en erkjennelse av elevens situasjon som unik. Både det unike ved eleven og det unike ved elevens kontekstuelle betingelser, i samspill med foreldre, medelever, lærere, arbeidsgivere og andre eksterne aktører må tas i betraktning for å sikre optimal vekst. Relasjonen og kommunikasjonen med eleven blir derfor av stor betydning. Denne kommunikasjonen må innebære respekt for elevens innsats og elevens ulike valg (Dyrnes, 2011; Lassen \& Breilid, 2010).

Lassen (2008: 159) oppsummerer en bestyrkningstilnærming på følgende vis:

a) Læring skjer gjennom kompetanseoverføring, systematisk støtte til utprøving av nye strategier og gjennom å gjøre valg.

b) Bestyrking skjer gjennom utvidelse av sosio- økologiske nettverk og personlig anerkjennelse.

c) Mestring synliggjøres gjennom fokus mot styrker og ressurser. Det er viktig at eleven opplever at endring avhenger av egne handlinger, og ikke av andres. Hvis andres valg er retningsgivende for eleven kan dette betraktes som uetisk og kan bidra til å forlenge behovet for hjelp (Brudal, 2006; Lassen, 2008).

Disse tre overordnede kategorier vil danne utgangspunkt for artikkelens drøftingsdel.

I denne studiens analyser har vi tatt utgangspunkt i problemstillingen; Hvilke bestyrkende faktorer kan fremme positive overganger fra skole til varig arbeidslivstilknytning for elever $i$ laerekandidatordningen?

For lærekandidater vil nettopp et mulighets- og bestyrkingsfokus være relevant med tanke på overgangen til en varig arbeidslivstilknytning. I de empiriske analysene vil vi derfor søke å finne elevenes beskrivelser av empowerment - faktorer som de har opplevd som viktige for å sikre god overgang mellom skole og varig arbeidslivstilknytning.

\section{Metode}

I arbeidet med spørsmål knyttet til lærekandidatordningen og overgang til en varig arbeidslivstilknytning, fikk prosjektgruppen tildelt regional kvalifiseringsstøtte fra Oslofjordfondet i 2014. Finansiering til forprosjekt gjorde det mulig å gjennomføre et forprosjekt for å utvikle kunnskap om ulike faktorers betydning med tanke på overgang fra 
videregående opplæring til varig arbeidslivstilknytning. Fordi prosjektet ble definert som et forprosjekt, ble dimensjonene på datainnsamlingen forholdsvis begrenset. Begrunnelsen for utvalget av informanter er dermed både av praktisk og av økonomisk karakter (Befring, 2007). Det empiriske materialet til artikkelen baseres på fire kvalitative intervju med ungdom som har lærekandidatkontrakt i bedrift. Begrunnelsen for utvalget har sitt utgangspunkt i artikkelens problemstilling. Målet med studien var derfor å anvende forprosjektet til å identifisere faktorer som kunne forfølges i senere studier. Informantene er alle over 18 år og de har gitt skriftlig informert samtykke til deltakelse i undersøkelsen. Prosjektet er vurdert og godkjent av NSD.

Intervju med målgruppen vil kunne bidra til å utvikle innsikt i temaet med utgangspunkt i deltakernes unike perspektiver (Kvale, Brinkmann, Anderssen \& Rygge, 2009). Gjennom å utforske meninger, meningskonstruksjoner og erfaringer knyttet til informantenes perspektiver, har vi hatt muligheter til å utvikle kunnskap gjennom informantenes beskrivelser om hva som bidrar positivt til myndiggjøring og tilrettelegging i deres prosess fra videregående opplæring til varig yrkeslivstilknytning.

Som metode for datainnsamling ble det valgt semi-strukturerte intervjuer som kjennetegnes av forhåndsbestemte temaer, men med muligheter for at informantene selv kan utdype aspekt som er viktige for dem. Intervjuene ble gjennomført av en prosjektmedarbeider, og intervjuenes varighet var ca. 45 minutter pr. informant. Målet med datainnsamling og analyse/diskusjon av data er å utvikle kunnskap om et spesifikt område (Bostad, 2008; Kvale \& Brinkmann, 2009). Begrunnelsen for valget av denne intervjuformen er at vi ønsket å få tak i informantenes subjektive opplevelser av problemstillingens tematikk, og at ny forståelse om dette kunne konstrueres i samhandling mellom informant og intervjuer. Intervjuene er tatt opp på lydopptaker. Lydopptakene er transkribert og analysert gjennom bruk av analyseverktøyet NVivo 11. NVivo er et dataprogram som støtter kvalitative data og «mixed-methods» (Creswell \& Clark, 2007).

\section{Utvalg}

Kriteriet for rekruttering av informanter til studien har vært yrkesfagelever som har hatt spesialundervisning i videregående opplæring, og som har hatt god erfaring med faktorer som sikrer en varig tilknytning til arbeidslivet etter videregående opplæring. 
Begrunnelsen for utvalgskriteriene var at ungdommene skulle ha tilstrekkelig grunnlag til å kunne reflektere over og sette ord på egne skolelivserfaringer fra grunnskole, videregående skole og arbeidsliv. I disse historiene vil særlig ungdommenes erfaringer med overganger bli vektlagt. I dette lå en forventning om at de evnet å reflektere over hvem og hva som har bidratt til at de er der de er i dag med tanke på varig arbeidslivstilknytning. Som hovedinformanter søkte vi lærekandidater i bedrift med mer enn ett års erfaring fra samme arbeidsplass. For å rekruttere informanter tok vi kontakt med to yrkesfaglige videregående skoler med en omfattende spesialpedagogisk virksomhet. Det pedagogiske personalet ved skolene formidlet kontakt med tidligere elever som hadde opplæringskontrakt i bedrift. Elevene representerte programområdene Naturbruk (NA) (én informant) og Teknikk- og Industriell Produksjon (TIP) (tre informanter). Med utgangspunkt i vår rekruttering av informanter, kan utdanningsprogramrekrutteringen framstå som «skjev» fordi tre av informantene er rekruttert fra Teknikk og Industriell Produksjon og en er rekruttert fra Naturbruk. Dette er ikke et representativt bilde for lærekandidatordningen i yrkesfag (Utdanningsdirektoratet, 2016). Grunnen til vårt utvalg er at det er disse utdanningsprogrammene som var representert ved skolene vi hadde tilgang til. Utvalget kan dermed betegnes som pragmatisk (Befring, 2007).

\section{Analyse}

En analytisk tilnærming omfatter å sammenfatte og formidle ulike mønstre som framkommer i intervjuene med utgangspunkt i problemstillingen (Hatch, 2002; Kvale et al., 2009; Thagaard, 2003). Mer spesifikt er utgangspunktet for våre analyser «tematisk analyse» (Braun $\&$ Clarke, 2006). Tematisk analyse er en tilnærming som identifiserer, analyserer og beskriver mønstre og ulike tema i et datamateriale.

Brown \& Clarke (2006) gir i sin artikkel en innføring i fremgangsmåten til bruk av tematisk analyse. Med betydelig inspirasjon fra Brown og Clarkes anvisninger fors $\varnothing \mathrm{kte}$ vi allerede under datainnsamlingsprosessen og arbeidet med transkribering, å identifisere meningsbærende mønstre/temaer av spesiell interesse for videre bearbeiding. I denne fasen av analysen ble det notert og drøftet ulike ideer om temaer som framkom i materialet. Det neste skrittet i analyseprosessen omfattet innledende systematisk sortering og koding. Gjennom dette arbeidet ble det avdekket ulike sentrale temaer av potensiell betydning for problemstillingen og det ble samlet relevante utsagn potensielle temaer/undertemaer. Videre ble de ulike temaenes relevans unders $\varnothing \mathrm{kt}$ med utgangspunkt i problemstillingen gjennom 
dannelsen av analytiske «tematiske kart». I dette arbeidet var bruk av NVivo 11 et nyttig verktøy.

Det «tematiske kartet» ble deretter anvendt for kategoribenevninger og kategoriene som samsvarte med problemstillingen ble forfulgt gjennom utvikling av tydelige definisjoner og benevning. Tematisk analysearbeid er ikke en lineær prosess. Det kreves en veksling mellom de ulike trinnene i prosessen for å ende opp med valide og reliable tema og kategorier.

I kvalitative studier deles validitet gjerne i intern og ekstern validitet (Dalen, 2011). Intern validitet innebærer i hvilke grad resultatene er gyldige for utvalget og fenomenet som er unders $\varnothing \mathrm{kt}$. I vår studie fikk informantene lese gjennom det transkriberte materialet for «sitt» intervju, og de tilsluttet seg og bekreftet at innholdet var relevant med utgangspunkt i problemstillingen. Ekstern validitet i kvalitative studier omhandler i hvilken grad resultatene kan overføres til andre utvalg og situasjoner. Utvalget i denne studien er ikke stort, men vi fant overlappende svar i de ulike intervjuene som kan antyde at funn fra denne studien kan sammenfalle med opplevelser i andre, tilsvarende utvalg.

Reliabilitet i kvalitative studier kan også kategoriseres i indre og ytre reliabilitet. Dalen (2011) definerer indre reliabilitet som «I hvilken grad andre forskere kan anvende begrepsapparatet for analysen av data på samme måte som den opprinnelige forskeren» (Dalen, 2011). I denne studien er det brukt svært konvensjonelle termer som er lett gjenkjennbare fra lovverk, forskrifter og veiledere som anvendes i videregående skoler og som også er godt kjent for arbeidsgivere som er mottakere av elever inn i yrkeslivet. På samme vis vil begrepsapparatet også være kjent for forskere - og nye analyser av materialet vil trolig føre til sammenfall av funn (ytre reliabilitet).

\section{Etiske betraktninger}

Vi har gjennom hele prosessen blitt stilt overfor ulike dilemmaer i gjennomføringen av prosjektet som har avkrevd etiske overveielser. I dette avsnittet vil vi omtale noen områder hvor vi har vært stilt overfor dilemmaer: vurdering av sensitiv informasjon, forskerens posisjon som «insider» og «outsider», maktrelasjoner mellom ulike aktører og frivillighet, personvern og anonymisering. Som forskere har vi ikke hatt tilgang til de unges IOP (individuell opplæringsplan) eller annen sensitiv informasjon som omhandler den enkelte. Våre funn og analyser av disse baseres derfor på hva de unge har sagt under intervjuene. 
Deltakelse i studien har vært frivillig, og informantene er kontaktet og forspurt om de vil delta via deres tidligere kontaktlærer ved den videregående skolen de gikk på. Til tross for at denne studien baseres på frivillig deltakelse, er det viktig at vi som forskere er oss bevisst vår rolle både med tanke på den makt vi besitter som fagpersoner, forskere og vår relasjon til skole og utdanningssystemet. Det innebærer blant annet at vi må ha høy etisk bevissthet i møtet med informantene og under behandlingen av materialet med tanke på å ivareta personvern og anonymisering. Dette kan være utfordrende med et såpass lite/begrenset materiale, men vi har under hele prosessen hatt høy bevissthet om dette.

Anonymisering er en annen utfordring som det er aktuelt å ha fokus på innenfor kvalitativ forskning. Den presentasjonsformen vi har valgt er den vi antar vil best ivareta integriteten til de medvirkende og vårt ønske om at materialet skal gi mening.

\section{Resultat:}

Analysekapitlet vil ta sitt utgangspunkt i de ulike skrittene som er skissert i tematisk analyse (Braun \& Clarke, 2006). Artikkelens teoretiske rammeverk har i stor grad utgangspunkt i foreliggende empiri. Informantenes svar viste eksempler på ulike faktorer som kan gjenfinnes i Lassens oppsummering av bestyrkningstilnærmingen hvor det blir det lagt vekt på at bestyrking skjer gjennom: kompetanseoverføring, systematisk støtte til utprøving av nye strategier og gjennom å gjøre valg; at bestyrking skjer gjennom utvidelse av sosio- $\varnothing$ kologiske nettverk og personlig anerkjennelse; at bestyrking synliggjøres gjennom fokus mot styrker og ressurser (Lassen, 2008). Disse kategoriene vil danne den videre strukturen i vår framstilling. Materialet viste dermed at empowerment-prosesser er viktige for å utvikle nødvendig kompetanse og fremme forutsetninger for varig arbeidslivstilknytning for yrkesfagelever med spesialundervisning.

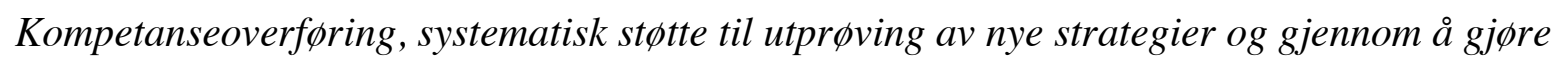
valg:

Eksempler på kompetanseoverføring, systematisk støtte til utprøving av nye strategier og å gjøre valg er informanten som sier at hun mener hun har blitt sterkere av at hun har blitt «pusha» og utfordret på skolen og på arbeidsplassen (Informant 4, kvinne 18 år. NA s. 12) Et annet eksempel på dette er informanten som sier at han opplever å ikke ha blitt forstått i grunnskolen. Han sier at han har opplevd å bli møtt med forståelse for sine behov både på videregående skole og på arbeidsplassen, og at det har medført at han har mestret både 
overgangen fra videregående skole til arbeid og ikke minst mestret å få en tilknytning til arbeidsplassen (Informant 3, mann 18 år, TIP). Det framkom også underkategorier, altså kategorier som bidrar til å konkretisere vår forståelse av fenomenet «empowerment» med utgangspunkt i valgt teori og tilgjengelig empiri.

En av informantene svarte på spørsmål om han likte arbeidsoppgavene og hadde tilstrekkelig kompetanse å utføre disse:

Ja, ja, jeg syns det er morsomt å drive med det. Det er det jeg liker å holde på med, å jobbe på verksted, og...

Nei, jeg kunne ikke alt. Men jeg har jo hatt som hobby og holdt på i garasjen siden jeg var liten. Så da, det hjelper jo litt... (informant 1, mann 18 år, TIP)

Informanten har hatt sitt videregående skoletilbud tilknyttet utdanningsprogrammet TIP (teknikk og industriell produksjon). Han sier at han har hatt og har interesse av å jobbe med oppgaver relatert til det yrkesområdet han utdanner seg til. Utsagnet kan stå som eksempel på betydningen av å ivareta og anerkjenne eksisterende ressurser og bygge videre på disse i yrkesøyemed. Det å anerkjenne at informanten har muligheter innen dette området i stedet for å fokusere på de eventuelle utfordringene han har, kan bidra til å fokusere på å bestyrke ungdommene gjennom medbestemmelse og deres ansvar for egen utvikling. Det å få arbeide med og videreutvikle kompetanse innenfor meningsfulle områder der informanten har spesielle interesser og grunnleggende kompetanse, vil være av betydning for overgangen fra skole til varig yrkesliv.

Når det gjelder medbestemmelse og medvirkning er det en relativt unison oppfatning blant informantene at de i liten grad har hatt innflytelse og eierskap til overordnet planverk for opplæringen (IOP). På spørsmål om informanten har sett sin individuelle opplæringsplan fra videregående skolesvarte informanten; Jeg har sikkert sett den, men jeg husker ikke noe av det. Jeg veit ikke om dem har det på skolen ennå en gang, jeg. (Informant 2, mann 18 år, TIP) I utsagnet viser informanten at planverk i skolen i hovedsak er det pedagogiske personalet som forvalter. Informanten opplever derfor at det er lærer som har eierskap til planene. Utsagnet anskueliggjør utfordring med medvirkning og dermed også myndiggjøring av elevene i skolen. 
Med tanke medbestemmelse i opplæring i bedrift viser informant 1 et annet bilde: $J a$. M-m . Jeg har en plan da som de har lagt opp her... Pluss at det opplegget de har laga her, er visstnok sånn de aller beste skal gjфre det, holdt jeg på å si, de som driver med det som har laerlinger hele tida, skal lage. Så de har ganske bra oppsett, dem her. (Informant 1, mann 18 år, TIP)

På spørsmål om hvor ofte de jobbet med planen svarte han; Vi gjør det en gang i uka.For det (planen) bytter nesten hver uke. (Informant 1, mann 18, TIP)

Informantens utsagn viser at medvirkning og medbestemmelse $\mathrm{i}$ egen opplæring $\mathrm{i}$ bedrift $\mathrm{i}$ større grad kan bidra til å myndiggjøre eleven. Her ser vi en forskjell i praksis mellom skole og bedrift.

Bestyrking skjer gjennom utvidelse av sosio- $\phi k o l o g i s k e ~ n e t t v e r k$ og personlig anerkjennelse: I intervju-materialet er det gjennomgående enighet om at alle informantene vektlegger betydningen av støtte fra uformelle og formelle nettverk på veien mot varig yrkesdeltakelse. Et system- økologisk perspektiv som innebærer å involvere og inkludere informantens totale livskontekst, ser ut til å ha betydning i bestyrkingsprosessen. I vårt tilfelle omhandler dette i særlig grad de ulike livsarenaene: hjemme, sammen med venner, skole og arbeidsliv. Alle informantene svarer at særlig foreldres involvering har vært betydningsfull på veien mot varig yrkesdeltakelse.

Dem har jo hjelpa meg masse, dem, og støttet meg opp og bare sagt «NN, du må liksom prøve å ta deg sammen og skjerpe deg og fullføre skolen, for da blir det så mye lettere videre i arbeidsliv og. Du må ha deg en utdannelse liksom». Så da gjorde jeg det. (Informant 3, mann 18 år, TIP)

En av informantene fortalte at foreldrene hadde motivert ham, hadde bedt ham om å ta seg sammen og hjulpet ham videre når de så at han trengte det. Det er mye takket være foreldrenes støtte at han nå er i arbeid, og i ferd med å oppnå formell kompetanse i yrket. En annen informant var klar på at det har vært av stor betydning å ha foreldre og venner å støtte seg til og snakke med når det har oppstått problemer av ulik art i løpet av skole- og yrkeslivet. Det har vært viktig med noen som har «ordna opp» og noen som har forstått hva informanten har hatt behov for av støtte og hjelp. 
Elevmedvirkning og elevdeltakelse er sentrale begreper i skolen. Det handler om elevenes egne erfaringer, perspektiver og oppfatninger, dvs. hvordan skolelivet, her opplæringsarenaen ser ut for informanten selv. Spørsmålet er; hva slags kompetanse har lærere i å lytte og kommunisere? (Tangen, 2014a, s. 161)

Vi ser eksempler på at det å arbeide sammen med en annen er med på å styrke og bygge på den kompetansen eleven innehar fra før. Formelle og uformelle former for støtte som kan $\emptyset \mathrm{ke}$ sannsynligheten for at eleven blir ivaretatt. En av ungdommene sier om kontaktlæreren sin på videregående skole:

Han var i hvert fall veldig flink sånn til å få folk ut. Det var sikkert noen andre og. Men det var han som var kontaktlæreren min da, så det var jo han som hjalp meg med å finne sted og sånne ting. Så jeg trivdes her, så var det jo å prøve å søke lærling ved hjelp av han. Han hjalp meg med å, når jeg fikk vite at jeg ble lærling her, så fikk jeg jo sånn lapp at jeg kunne gå og kjøpe noe arbeidsutstyr, og han hjalp meg og viste hvor det var og ble med meg dit og. (Informant 1, mann 18 år, TIP)

\section{Vektlegging av den enkeltes ressurser framfor vektlegging av utfordringer:}

Videre finner vi at ved å fokusere på ungdommenes ressurser, muligheter og styrker i stedet for utfordringer på skolearenaen og i arbeidslivet, kan man bidra til at de selv finner ut av hvordan egen kompetanse kan økes og oppgaver løses. Ungdommene er tydelige på hvordan en trygg relasjon til de voksne medfører trygghet til å spørre om hjelp og veiledning når det trengs. Vektlegging av ressurser er en bestyrkende faktor som på sikt vil bidra til å kunne ta i bruk egne ressurser og kompetanse i møtet med utfordringer og hindringer i hverdagen på arbeidsplassen. Dette er både kompetansestyrkende og generelt bestyrkende prosesser. Informantene uttrykker dette om betydningen av trygge relasjoner:

Det er jo, man kan ikke bare sitte lukka inne i et skall hele livet eller noe sånt. Jeg har jo vært litt irritert noen ganger når jeg har blitt pusha og når jeg ikke vil bli pusha. Men det har lønt seg. Det har jo det. Jeg har begynt å tåle litt mer også. Ja, de andre sier jo at i løpet av den tida som jeg har vært lærekandidat, så har det vært masse forandringer. At siden jeg har startet å jobbe, har jeg liksom begynt å tåle mer, og har blitt litt sterkere på det. M-m. (Informant 4, kvinne 18 år, NA)

Bestyrking gjennom støtte og anerkjennelse framstår dermed her som en vesentlig faktor i arbeidet med å sikre godt innhold i skolen, samt gode overganger til varig arbeidslivstilknytning. 


\section{Bestyrking synliggjøres gjennom fokus mot styrker og ressurser:}

Informantene vektlegger betydningen av gode relasjoner til lærer og arbeidsleder når det er behov for hjelp til å utføre en arbeidsoppgave eller når det skjer noe uforutsett som må løses eller takles. Det gir god støtte og trygghet å vite at det er noen å spørre om hjelp og støtte til å utvikle faglig- og sosial kompetanse i arbeidshverdagen. I en empowerment-tradisjon vil samarbeid og partnerskap vektlegges i bestyrkningsarbeidet. Samarbeid og partnerskap vil kreve utvikling av gjensidig og anerkjennende kommunikasjon i det asymmetriske forholdet som alltid vil prege lærer/elev- og arbeidsgiver/arbeidstakerrelasjoner. Om dette sier en av informantene:

Den største utfordringa for meg, det har vel vært det at jeg ikke har blitt forstått, kan du si. Det er ingen som har forstått meg selv om jeg har prøvd å snakke med lærere og sånne ting. Så dem forstår ikke mine problemer da. Jeg tror egentlig bare at dem driter i det, at så lenge du ikke er A4 liksom og ikke klarer det som alle andre, da er du søppel og da kan du komme deg ut, ikke sant. Så det har nok vært den største utfordringa for meg. For hjemme så har det gått kjempebra. Men på skolen da var jeg mye sinna og frustrert og gikk dårlig sammen med andre siden jeg var, jeg var irritert, og andre barn visste at jeg ble sinna og da var jo det kjempekult. (Informant 3, mann 18 år, TIP)

Her ser vi et eksempel på hvordan det ikke er blitt tatt utgangspunkt i elevens behov, og at det dermed ikke har oppstått en forståelse for hva som må iverksettes av tiltak og bestyrkingsprosesser overfor den enkelte. Det handler også om hvordan formell og uformell støtte kan bidra i bestyrkingsprosessen. Dette er også et eksempel på hvordan manglende fokus på samarbeid og partnerskap preget av gjensidig anerkjennende kommunikasjon mellom lærer og elev kan ses på som problematisk i bestyrkingsprosessene. Gode bestyrkingsprosesser vil heller ivareta informantens rett til medvirkning og medbestemmelse i eget liv.

I våre funn er det klare indikasjoner på at gode relasjoner, fokus på ressurser framfor utfordringer, stabile og støttende formelle og uformelle nettverk i medbestemmelsesprosesser kan være sentrale bestyrkningsfaktorer på vei mot varig arbeidslivsdeltakelse for yrkesfagungdom med spesialpedagogiske tilbud. Bestyrkende samarbeid forutsetter dermed et perspektiv som kjennetegnes av anerkjennelse, tro på ressurser og at de ulike aktørene deler framtidsfokus. Resultatene kan sammenfattes i tre områder: Opplæringen må være yrkesrelevant og meningsfull, og ungdommene må oppleve reell medbestemmelse på innhold og organisering av opplæringen, og at læringsutbyttet har sammenheng med ungdommens læringsbehov og interesse. 


\section{Drøfting:}

I denne studiens analyser har vi tatt utgangspunkt i problemstillingen; Hvilke bestyrkende faktorer kan fremme positive overganger fra skole til varig arbeidslivstilknytning for elever $i$ larekandidatordningen? For våre informanter har et mulighets- og bestyrkingsfokus vært av betydning for opplevelse av meningsfulle lærings- og utviklingsprosesser i skolen og i tilknytningen til arbeidslivet. I drøftingen vil vi ta utgangspunkt i Lassens forståelse av bestyrkingsprosesser (2008), samt konklusjoner fra VET-studien som ble presentert i teoriavsnittet (European Agency for Special Needs and Inclusive Education, u.å.).

Informantene i undersøkelsen har gitt oss sitt syn på hvilke praksiser som har bidratt til at de i dag er i arbeid. Funn fra undersøkelsen er særegent for våre fire informanter. Samtidig synes funn fra denne studien å sammenfalle med betydningsfulle faktorer som kan gjelde andre med spesialpedagogiske behov i skolen og som kan ha utfordringer med å oppnå varig arbeidslivstilknytning (European Agency for Special Needs and Inclusive Education, u.å.).

I tråd med opplæringslovens intensjoner om å «åpne dører ut mot verden» og intensjonene $\mathrm{i}$ kapittel fem om å etablere opplæring med realistiske og framtidsrettede mål (Opplæringslova, 2007), vil empowerment-tilnærming i skole og bedrift kunne bidra til å sikre eleven et meningsfullt voksenliv i en varig arbeidslivstilknytning.

Vi har tidligere problematisert at spesialundervisning kan oppleves som et pedagogisk område hvor ulike grunnforståelser kan prege de ulike spesialpedagogiske praksisene. Ensidig fokus mot individuelle utfordringer eller ensidig fokus mot utfordringer i opplæringskonteksten kan bidra til å begrense elevens utviklingsprosesser. Et relasjonelt perspektiv som vektlegger både miljøets betydning og elevens forutsetninger for å nå forente mål, vil i større grad også kunne romme medvirkning og bestyrking fordi oppmerksomheten dreies fra å være ensidig fokusert på manglende forutsetninger, til å fokusere på muligheter for funksjon og positive bidrag i arbeids- og samfunnsliv.

\section{Anvende og utvikle elevens kompetanse - mestring og mening}

Vi ser av materialet at informantene i stor grad opplever at oppgaver som utfordrer mestring kan bidra til meningsskaping. Dette gjelder både i skole og bedrift. På denne måten vil oppmerksomhet kunne dreies fra å være fokusert på individenes manglende forutsetninger, til 
et mulighetsfokus. Informantene opplever at det å bli utfordret til å anvende og utvikle egne ressurser i skole og bedrift, bidrar til å bestyrke deres kompetanse og egenverd.

En utfordring i pedagogisk arbeid vil derfor være å styrke elever med behov for støtte gjennom aktivt og målrettet samspill med relevante samarbeidspartnere. En slik myndiggjøring vil kunne bidra til at egenskaper som fremmer muligheter for frigjøring og kontroll over egen situasjon og eget liv kan bestyrkes.

\section{Betydningen av relasjon, kommunikasjon og velfungerende sosio- $\phi$ kologiske nettverk} I materialet finner vi at foresatte og venner er viktige faktorer med tanke på elevens gjennomføring av skolegangen og for overgangen til en varig arbeidslivstilknytning. På samme måte ser vi at de formelle nettverkene er av stor betydning med tanke på praktisk tilrettelegging, støtte og anerkjennelse. På denne måten opplever informantene at uformelle og formelle nettverk har hatt stor betydning for å sikre varig arbeidslivstilknytning. God samhandling mellom elevens ulike uformelle og formelle nettverk vil dermed ha betydning for den enkelt ungdoms muligheter. I disse prosessene opplever informantene at samarbeid og partnerskap med ulike aktører har hatt stor innflytelse på deres læring og utvikling på vei mot varig arbeidslivstilknytning.

\section{Betydningen av elevmedvirkning og elevmedbestemmelse}

Et dilemma som oppstår som følge av spesialundervisningens grunnlagsforståelse, rettighetsforankring og individuelle orientering, er hvordan opplæringen kan gjennomføres uten at det bidrar til marginalisering, segregering, umyndiggjøring eller utestenging fra fellesskapet. Hvorvidt opplæringen blir etisk og faglig problematisk, vil derfor være avhengig av om tiltakene bidrar til å redusere eller $\varnothing \mathrm{ke}$ den enkeltes muligheter til samspill og demokratisk deltagelse. Våre informanter oppgir at de har positive erfaringer med medvirkning og medbestemmelse gjennom arbeid med egne mål og utarbeidelse av planleggingsdokumenter slik de opplever dem i sin nåværende arbeids-/opplæringssituasjon. Innsikt og medvirkning i utarbeiding og evaluering av egen plan, og deltakelse i vurdering av innsats og måloppnåelse er her et viktig element i deres myndiggjøringsprosess.

I tråd med opplæringslovens intensjoner bør planverk i skole og bedrift i stor grad være kompetanse- og ferdighetsrettet med tanke på yrkes- eller grunnkompetanse. Dette vil også sørge for en god kopling mellom ordinær undervisning og spesialundervisning. Å etablere en 
god sammenheng og kopling her vil gi ungdommene en oversikt og sammenheng i skolehverdagen, som i mange tilfeller synes å mangle. I materialet viser informantene at planverket i skolen i hovedsak forvaltes av det pedagogiske personalet. Informantene opplever derfor at det er lærer som har eierskap til planene. Utsagnet anskueliggjør utfordringer med tanke på medvirkning og dermed også myndiggjøring av elevene i skolen. Dette kan være en faktor som bidrar til utfordringer i overgangen skole - varig arbeidslivstilknytning. Informantene oppgir imidlertid at muligheter for medvirkning og medbestemmelse oppleves annerledes i bedrift. Her viser utsagn at elevene er betydelig mer delaktige i plan- og evalueringsprosesser. Praksis viser derfor at skolen kan ha nytte av tettere samhandling med elever og bedrifter.

Oppsummert kan vi si at relasjoner, kommunikasjon og anerkjennelse i de ulike kontekstene ungdommene lever og deltar i er av stor betydning for deres muligheter for å styrke egenverd, kompetanse og framtidsmuligheter. Ut av våre dialoger med informantene, ser vi en særlig betydning av fleksibilitet, medvirkning/medbestemmelse, koordinerte overganger og det relasjonelle blikk/samhandling som viktige faktorer for at denne elevgruppen skal kunne oppnå varig arbeidslivsdeltakelse.

\section{Avslutning}

Denne artikkelens tematikk og problemstilling har omhandlet å identifisere bestyrkningsfaktorer som kan bidra til gode overganger mellom skole og varig arbeidslivstilknytning for elever i lærekandidatordninger. Bevissthet og kunnskap om denne problematikken er relevant med tanke på lærerutdanning og praktisk pedagogisk arbeid i skole og bedrift. Interesse for og kunnskaper om elevens forutsetninger og nettverk vil være en viktig faktor for gode overganger. Pedagogisk praksis som inkluderer elevens livsverden er også betydningsfull. Dette vil kunne utfordre rådende praksis i skole. Gjennom arbeid i gode nettverk vil alle aktører oppleve bestyrking. Dette vil omfatte elever, foreldre, lærer, instruktører og andre aktuelle samarbeidspartnere. Erfaringene våre med at dette er et noe uutforsket felt og vår interesse for feltet, både med tanke på spesialpedagogikk og yrkesutdanning gjør at vi planlegger å forske videre på dette. Vi ønsker i neste runde å se spesielt på systemene rundt ungdommene og hvordan aktørene kan bidra til myndiggjøring av den unge og hvordan systemet selv kan myndiggjøres i samhandlingen med og om den unge på veien mot yrkesdeltakelse. 


\section{Referanser:}

Askheim, O. P. (2003). Fra normalisering til empowerment: ideologier og praksis $i$ arbeid med funksjonshemmede. Oslo: Gyldendal akademisk.

Befring, E. (2007). Forskingsmetode med etikk og statistikk. Samlagets bøker for høgare utdanning, 2. utg., Oslo: Samlaget.

Befring, E. (2008). Forebygging i en psykososial kontekst. I E. Befring \& R. Tangen (Red.), Spesialpedagogikk (s. 170-191). Oslo: Cappelen Damm akademisk.

Befring, E. \& Tangen, R. (2012). Kapitteltittel. I E. Befring \& R. Tangen (Red.), Spesialpedagogikk (5. utg., s. 1-12). Oslo: Cappelen Damm akademisk.

Berzin, S. C. \& Kelly, M. (2009). Disability and Post-High School Transition: Does Placement in Special Eduction Improve Outcomes for Young People? Advances in School Mental Health Promotion, 2(2), 17-29. doi: 10.1080/1754730X.2009.9715701

Bostad, I. (2008). Synlige verdier og usynlig dobbeltmoral. I Å. Røthing \& O. Leirvik (Red.), Verdier. Oslo: Universitetsforlaget.

Braun, V. \& Clarke, V. (2006). Using thematic analysis in psychology. Qualitative Research in Psychology, 3(2), 77-101. doi: 10.1191/1478088706qp063oa

Breilid, N. (2007). Ungdom og laringserfaringer. En survey - studie av ungdoms laringserfaringer på ulike arenaer (Ph.d.). Universitetet i Oslo, Oslo

Bronfenbrenner, U. (1979). The Ecology of Human Development: Experiments by Nature and Design (Ecology of Human Development - Experiments by Nature \& Design). Cambridge, Mass.: Harvard University Press.

Brudal, L. F. (2006). Positiv psykologi, flyt, kvinne og mann, humor. Oslo: Fagbokforlaget.

Buli-Holmberg, J. (2012). Inkludering i arbeidslivet - overgang skole til arbeid for ungdom med særskilte opplæringsbehov. I R. T. Edvard Befring (Red.), Spesialpedagogikk (Bind 5, s. 665-689). Oslo: Cappelen Damm Akademiske.

Buli-Holmberg, J. (2015). Transitioning from school to work: oppotunities and challenges for young adults with special needs. I D. L. Cameron \& R. Thygesen (Red.), Transitions in the field of special education: Theoretical perspectives and implications for practice. Köln: Waxman.

Creswell, J. W. \& Clark, V. L. P. (2007). Designing and conducting mixed methods research. London: SAGE Publishing

Dalen, M. (2011). Intervju som forskningsmetode (2. utg.). Oslo: Universitetsforl.

Dunst, C. J., Trivette, C. M. \& Deal, A. G. (1994). Supporting \& strengthening families: methods, strategies and practices (Bind 1). Cambridge Mass: Brookline Books. 
Dyrnes, E. M. (2011). Hva mener elever ved yrkesfaglige program i den videregående skolen har betydning for at de skal fullføre utdanningen (Masteroppgave). Lillehammert: Høgskolen i Lillehammer

Dyrnes, E. M. (2013). Det gode møtet som motivasjon til å fullføre. Bedre skole (1), 65-68.

Egan, G. (2002). The skilled helper: a problem-management and opportunity-development approach to helping (7. utg.). Pacific Grove, Calif: Brooks/Cole.

European Agency for Special Needs and Inclusive Education. (u.å.). 20 key factors for successful vocational education and training. Hentet fra https://www .europeanagency.org/sites/default/files/agency-projects/vocational-education-andtraining/20KeyFactors14-EN.pdf

Guy, B. A., Sitlington, P. L., Larsen, M. D. \& Frank, A. R. (2009). What are high schools offering as preparation for employment? Career Development for Exceptional Individuals, 32 (1), 30-41.

Hatch, J. A. (2002). Doing qualitative research in education settings. Albany, N.Y: State University of New York Press.

Kvale, S. \& Brinkmann, S. (2009). Interviews: Learning the craft of qualitative research interviewing. New Dehli: Sage Publishing.

Kvale, S., Brinkmann, S., Anderssen, T. M. \& Rygge, J. (2009). Det kvalitative forskningsintervju (InterView[s] learning the craft of qualitative research interviewing, 2. utg.). Oslo: Gyldendal akademisk.

Lassen, L. M. (2008). Hvordan prinsippene i empowerment kan anvendes som metode ved spesialpedagogisk rådgivningsarbeid. I E. Befring \& R. Tangen (Red.), Spesialpedagogikk (4. utg., s. 154-169). Oslo: Cappelen akademisk forlag.

Lassen, L. M. (2014). Rådgivning: kunsten å hjelpe og sikre vekstfremmende prosesser (2. utg. utg.). Oslo: Universitetsforlaget

Lassen, L. M. \& Breilid, N. (2010). Den gode elevsamtalen. Oslo: Gyldendal akademisk.

Lassen, L. M. \& Breilid, N. (2012). Foreldresamarbeid i praksis: et verktøy for foreldre, laerere og elever for å skape utviklingsfremmende prosesser. Bergen: Fagbokforlaget

Lazarus, R. S. \& Folkman, S. (1991). The concepy of coping. I A. Monat \& R. S. Lazarus (Red.), Stress and coping. New York: Colombia University press

Markussen, E. (2009). Videregående opplaering for (nesten) alle. Oslo: Cappelen akademisk.

Markussen, E., Frøseth, M. W. \& Grøgaard, J. B. (2009). Inkludert eller segregert? Om spesialundervisning $i$ videregående opplaring like etter innføringen av Kunnskapslфftet. Oslo: NIFU STEP.

Meld. St. nr. 20 (2012-2013). (2013). På rett vei: Kvalitet og mangfold i fellesskolen. Hentet fra 
https://www.regjeringen.no/contentassets/53bb6e5685704455b06fdd289212d108/no/p dfs/stm201220130020000dddpdfs.pdf

Menon, S. (2001). Employee Empowerment: An Integrative Psychological Approach. Applied Psychology, 50(1), 153-180. doi: 10.1111/1464-0597.00052

Olaisen, K. (2007). Ungdom og utviklingsfremmende samtaler - et utviklingsprosjekt. Suicidologi. doi: 10.5617

Opplæringslova. (1998). Lov om grunnskolen og den vidaregåande opplaringa Hentet fra https://lovdata.no/dokument/NL/lov/1998-07-17-61

Opplæringslova. (2007). Lov av 17. juli 1998 nr. 61 om grunnskolen og den vidaregåande opplaringa. Oslo: Cappelen Akademisk.

Seligman, M. E. P. (2012). Flourish: A visionary new understanding of happiness and wellbeeing. New York: Free press.

Tangen, R. (2014a). Elevers skolekvalitet. I E. Befring \& R. Tangen (Red.), Spesialpedagogikk. Oslo: Cappelen Damm Akademisk.

Tangen, R. (2014b). Retten til utdanning for alle. I E. Befring \& R. Tangen (Red.), Spesialpedagogikk (s. 108-127). Oslo: Cappelen Damm akademiske.

Thagaard, T. (2003). Systematikk og innlevelse: en innføring i kvalitativ metode (2. utg. utg.). Bergen: Fagbokforl.

Utdanningsdepartementet. (2006). Lareplanverket for Kunnskapsløftet. [Oslo]: Utdanningsdirektoratet.

Utdanningsdirektoratet. (2016). Indikatorrapport 2016. Oppfølging av Samfunnskontrakt for flere laereplasser. Oslo: Utdanningsdirektoratet. 